\title{
Designing and Marketing a LibGuide for Presidential Papers
}

\section{A. Blake Denton}

W hen I joined the faculty at the Fred J. Taylor Library at the University of Arkansas at Monticello (UAM) in July 2019, I became the coordinator of our institution's Federal Depository Library Program and Arkansas Documents repositories. As I began inspecting our collections, I discovered that documents were dispersed throughout the library. Though the library has a designated Government Documents Collection cataloged under the SuDoc classification scheme, numerous documents were cataloged under the Library of Congress classification as well. Compounding this issue, documents classified under LC were distributed across various collections. The distribution of government documents across multiple collections is not unique to UAM, and is a common problem among FDLP depositories. ${ }^{1}$ Having government documents classified under different schemes and shelved in multiple collections can lead to discrepancies in cataloging, particularly as personnel change over time. Finding multiple split-cataloged series in our collections convinced me that, with rare exception, documents should be consolidated into a revamped Government Documents Collection.

Reintegrating the Public Papers of the Presidents from the Main Collection into the Government Documents Collection was supposed to be a simple part of this ongoing consolidation project. ${ }^{2}$ Unforeseen issues arose, however, that transformed this seemingly straightforward task into a side project within this greater overhaul effort. The first hitch emerged when I realized that I could not transfer President Franklin D. Roosevelt's public papers to the Government Documents Collection because they were published privately. ${ }^{3}$ Our thirteen-volume set of public papers for one of America's most consequential presidents would remain in the Main Collection. ${ }^{4}$

Furthermore, I discovered that our ten-volume set of public presidential papers from George Washington to Grover Cleveland, published in the late nineteenth century, was still shelved in our Main Collection. ${ }^{5}$ I decided against transferring them to our Government Documents Collection due to the age and condition of the volumes. Instead, I transferred them to our Special Collections department to ensure long term preservation. These unanticipated problems meant that our public Presidential Papers could not be conveniently and clearly cataloged and shelved in the same collection as originally planned, but instead would remain distributed across three collections: the Main Collection, the Government Documents Collection, and the UAM Special Collections.

While I was not pleased that these circumstances hindered our consolidation policy for the documents collection, the primacy concern was how this would affect our patrons. How do we avoid confusion and misunderstanding with shelving these papers in three different locations? How do we prevent a patron from assuming our library does not have Roosevelt's public papers when they notice that the Public Papers of the Presidents skips from Hoover to Truman? Similarly, any user casually browsing the Government Documents Collection might infer that our library does not have public papers of presidents that served before Hoover, since Taylor Library's pre-twentiethcentury collection is not on the open floor with the others. I concluded we needed a new LibGuide specifically for the presidential papers so patrons would know which collection they need to explore depending on the commander-in-chief they are researching.

I created the LibGuide for presidential papers in January 2021 and completed it over the course of the spring semester while volumes were re-cataloged and transferred to their new locations. I initially envisioned a simple guide that would direct patrons to the collection that held their volumes of interest. During the brainstorming process, however, I concluded that this research aid should offer much more. In addition to directing users to the appropriate collections for access to the print volumes, this new guide also provides access to digital versions and other relevant resources. ${ }^{6}$

The "Public Papers" tab is divided by collection: The Government Documents Collection, Main Collection, and Special Collections. Under each collection, the guide lists series or titles with brief descriptions, provides call numbers for print editions, and information on whether these items are eligible for checkout. Where possible, links are included for digital versions available through GPO or HathiTrust. For inquiring minds, I subtly address the issue of Roosevelt's papers in my description of The Public Papers of the Presidents, writing "series includes the public papers of every president from Hoover to Obama, except for Franklin D. Roosevelt (published privately)."

Under the "Searching Public Papers" tab, the guide explains that volumes of the Public Papers of the Presidents include indices, and it notes that the digital versions linked on our LibGuide 


\section{Designing and Marketing a LibGuide for Presidential Papers}

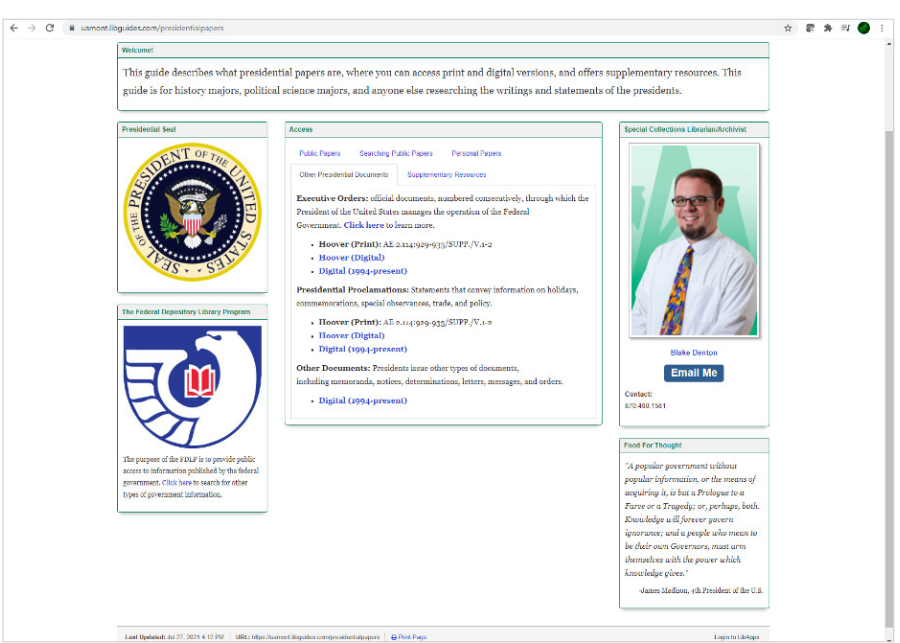

Figure 1. Other Presidential Documents Tab

are keyword searchable. While this basic research information might seem unnecessary to include, I have found that it is best to avoid making assumptions about patrons. A good LibGuide not only provides access to great resources but meets users in their research abilities and equips them with the knowledge to use those resources. For more comprehensive searching, I included a link to the American Presidency Project, hosted at the University of California, Santa Barbara. ${ }^{8}$ This superb website provides a database for presidential public documents searchable by keyword, document category, or president.

Though I did not originally intend to include personal presidential papers, the "Personal Papers" tab emerged as a natural extension of this LibGuide, which evolved into a resource that offers access to primary sources about the American presidency. This tab is organized into two categories: the Main Collection and Digital Collections. Readers might be surprised to learn that none of our relevant print volumes are listed under the Main Collection. Instead, it provides a link to our library's catalog and instructs patrons how to conduct author and keyword searches by president. When I searched through our catalog for personal papers of our presidents, I realized that our library held multiple titles for several of our presidents. An author search for Washington and Jefferson, for example, revealed five or more results for each.

I wrestled with an age-old dilemma for information professionals: comprehensiveness versus usability. A comprehensive list with call numbers offers researchers one convenient location to see what is available. However, this list might turn others away who do not want to scroll through a seemingly endless webpage to find the resources they need. After considering the needs of our campus community, I decided it was best to instruct students how to search for these papers in the catalog as opposed to providing a comprehensive list of our print volumes.

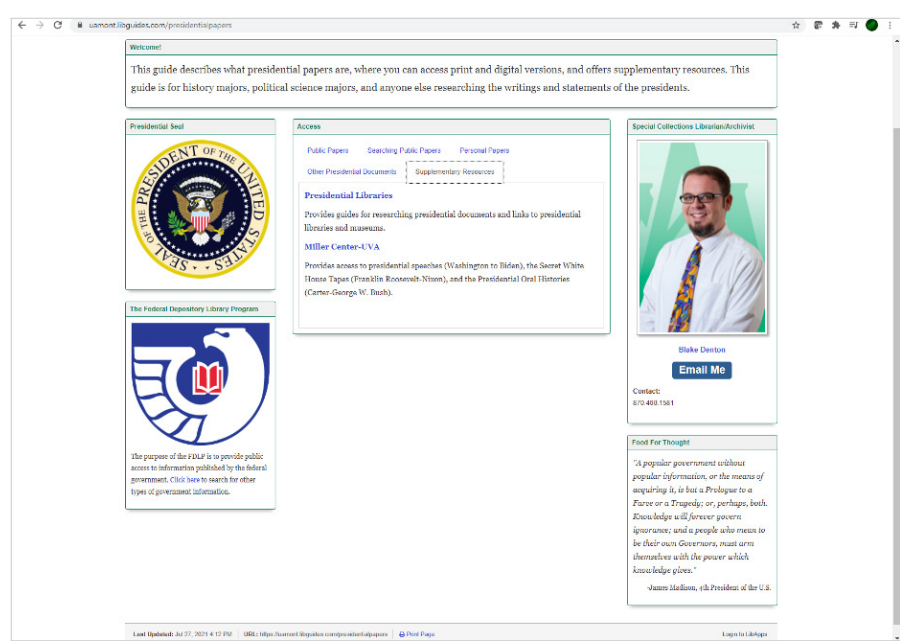

Figure 2. Supplementary Resources Tab

The "Personal Papers" tab also provides access to digital copies and transcripts of the personal papers for several early commanders-in-chief, specifically though the Library of Congress' digitized collection of papers from twenty-three various presidents spanning Washington to Coolidge.?

LibGuides are wonderful resources, but they are only useful if patrons know they exist. It is not sufficient to add new guides to your website-you have to market them! I employed three strategies for increasing our patrons' chances of exposure to this new LibGuide. First, I added a "Presidential Papers" tab within our Government Information, History, and Political Science guides. When users click on those tabs, they are greeted with the Seal of the President of the United States and a quick blurb that links to this new research guide: "Need to access presidential writings, addresses, or remarks? Check out our presidential papers guide!" This way, students who are browsing one of those other guides may stumble upon the Presidential Papers guide.

Second, I designed a physical sign and strategically placed it with our holdings of the Public Papers of the Presidents in the Government Documents Collection (see figure 3). The sign is designed to be distinctive and minimalist to catch and hold a browser's attention. Many of our students enjoy navigating the world through their smart phones, so I created a QR code through a free online generator and included it on the sign. Anyone passing through can instantly access the Presidential Papers LibGuide with a simple scan of their phone camera. For patrons who prefer to view content on larger screens, concise instructions are provided detailing how they can access the guide from our website.

My last strategy for raising awareness of the new LibGuide was through word-of-mouth. After I finished the guide and published it on April 28th, I emailed our history and political 


\section{Can't find a president's papers?}

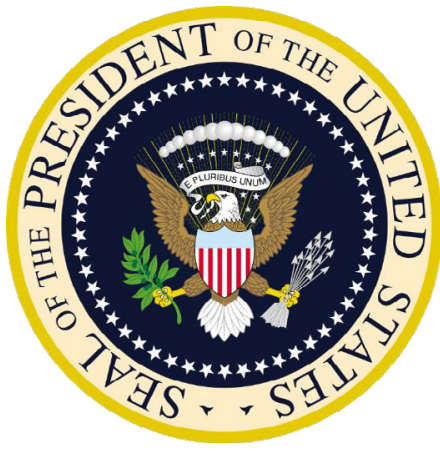

Need Inelp searching the papers?

\section{Scan the QR Code to learn more}

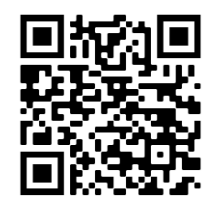

(or access from our website: Research Guides $\rightarrow$ Presidential Papers)

Figure 3. Physical sign located in Government Documents Collection

science faculty to inform them of this new resource. My director and I received compliments and expressions of appreciation from multiple colleagues for this new resource. According to our website's statistics, the guide enjoyed dozens of views within three months of going live. The results of actively marketing our new Presidential Papers LibGuide speak for themselves.

Taylor Library's government information consolidation project is an ongoing process. As a new FDLP coordinator, I did not anticipate the issues I would face when beginning this ambitious undertaking, particularly those concerning presidential public papers. While the circumstances described above prevented me from seamlessly transferring all presidential public papers to the Government Documents Collection, these challenges provided an invaluable opportunity for me to learn more about the nature of government information and digital resources available to patrons beyond the walls of Taylor Library. Most significantly, these complications ultimately led to the creation of a new research guide for faculty, students, and members of the public that reinforces the FDLP's vision to "provide Government information when and where it is needed in order to create an informed citizenry and an improved quality of life." ${ }^{10}$ Considering our new LibGuide's "food for thought" quote (see figures 1 or 2), I think Mr. Madison and other likeminded presidents would heartily approve. ${ }^{11}$

\section{Notes}

1. Andrew Lopez and Lori Looney, "Experience of a New Government Documents Librarian," in Government Information Essentials, ed. Susanne Caro (Chicago: American Library Association, 2018), 16-17.

2. Public Papers of the Presidents of the United States (Washington: Office of the Federal Register; National Archives and Records Administration, 1957-present).

3. "The Public Papers of the President were not published by the National Archives for the Franklin D. Roosevelt presidency; these volumes were published by a private printer before the commencement of the official Public Papers series." See "Public Papers of the Presidents of the United States," govinfo, accessed August 14, 2021, https://www .govinfo.gov/app/collection/PPP.

4. Samuel I. Rosenman, comp., The Public Papers and Addresses of Franklin D. Roosevelt (New York: Russell \& Russell, 1969).

5. James D. Richardson, comp., A Compilation of the Messages and Papers of the Presidents, 1789-1897 (Washington: Government Printing Office, 1896-99).

6. A. Blake Denton, "Presidential Papers," University of Arkansas at Monticello, Fred J. Taylor Library and Technology Center, last modified July 27, 2021, https:/uamont .libguides.com/presidentialpapers.

7. Denton, "Presidential Papers."

8. The American Presidency Project, University of California, Santa Barbara, accessed September 10, 2021, https:// www.presidency.ucsb.edu/.

9. "Library of Congress Completes Digitization of 23 Early Presidential Collections: Completion of Project Includes Latest Digitization of Papers of Presidents Benjamin Harrison, William Howard Taft, Grover Cleveland and Calvin Coolidge," Library of Congress news release, December 17, 2020, https://www.loc.gov/item/prn-20-085 /library-of-congress-completes-digitization-of-23-early -presidential-collections/2020-12-17/.

10. "FDLP Mission, Vision, \& Values," Federal Depository Library Program, last modified September 3, 2019, https://www.fdlp.gov/about-fdlp/mission-history/fdlp -mission-vision-values.

11. James Madison to W. T. Barry, August 4, 1822, Library of Congress, accessed August 14, 2021, https://www.loc .gov/resource/mjm.20_0155_0159/?sp=1\&st=text. 